\title{
FAKTOR YANG MEMPENGARUHI PERKEMBANGAN MORAL PADA ANAK USIA DINI
}

\author{
Mardi Fitri ${ }^{1}$, Na'imah ${ }^{2}$ \\ ${ }^{12}$ Universitas Islam Negeri Sunan Kalijaga Yogyakarta, Indonesia \\ mardifitri068@gmail.com
}

\begin{abstract}
Moral development on children is an important thing that must be understood for early childhood education practitioner or observer. Early child is a valuable asset for the future life of this nation and country. On that account the researcher did this research with the aim to understand the influential factor to moral development of early child. This research was qualitative research that used library research method. The data resources that used in this study are the literatures whichis related to early child moral development, namely the articles and books that concernd in this theme. The data analysis process is descriptive, that used methods: reducting data, displaying data and making conclution. The result of the study showed that moral development process of early child influented by internal and external factor. Both factors can be living contex, individual contex, and social contex or the way they interact with the social life. It given us the evidence that there are needed the parents or educators that understand about the influential factors in early child moral development process, so that they can guide them to be able in implementing the good moral behavior for the future.
\end{abstract}

Keywords:Early Childhood; Moral Development, Environmental Influence, Early Child Developmenal psychology.

\begin{abstract}
Abstrak
Perkembangan moral anak merupakan hal yang perlu untuk diketahui secara mendalam bagi praktisi atau pemerhati pendidikan anak berusia dini. Anak berusia dini merupakan asset berharga untuk keberlangsungan hidup bangsa dan negara di masa mendatang. Oleh sebab itu penulis malakukan penelitian ini dengan tujuan agar dapat memahami faktor yang berpengaruh terhadap perkembangan moral anak usia dini. Penelitian ini merupakan penelitian kualitatif dengan metode studi pustaka. Sumber data yang digunakan merupakan sumber dari literatur yang berkaitan dengan perkembangan moral anak usia dini, yakni berupa artikel-artikel jurnal ilmiah serta buku-buku yang membahas tema ini. Analisis datanya adalah analisis deskriptif yang menggunakan metode: mereduksi data, menganalisa data dan menarik kesimpulan. Sementara itu, hasil penelitian ini menunjukkan bahwa perkembangan moralitas anak yang berusia dini dipengaruhi oleh faktor dalam dan luar. Faktor tersebut dapat berupa keadaan situasi lingkungan, konteks individu atau kepribadian, dan konteks sosial atau cara berintraksi dengan lingkungan sekitar dalam bermasyarakat. Hal ini membuktikan bahwa perlu adanya peran orang tua atau pendidik yang memahami faktor-faktor yang berpengaruh terhadap perkembangan moral anak, agar dapat membimbing para anak untuk mampu berperilaku moral yang baik pada masa yang mendatang.
\end{abstract}

Kata Kunci: Anak Usia Dini; Perkembangan Moral, Pengaruh Lingkungan, Psikologi Perkembangan Anak Usia Dini

\section{PENDAHULUAN}

Anak-anak merupakan asset yang sangat berharga bagi bangsa dan negara. Mereka merupakan calon-calon penerus yang akan menjadi sumber daya manusia yang akan melanjutkan dan menentukan kelangsungan hidup di masa mendatang di dalam kesatuan tubuh bangsa dan negara. Maka dari itu, memberikan perhatian yang mendalam bagi kepentingan pendidikan 
mereka merupakan hal yang mesti dilakukan. Salah satunya adalah dengan memberikan perhatian pada perkembangan psikologisnya. Perkembangan psikologis menjadi esensi yang penting untuk dimengerti, oleh karena dengan memahami perkembangan psikologisnya, proses pendidikan akan semakin mudah dan mengena. Perlu dicatat, bahwa setiap anak mempunyai tingkatan psikologis yang tidak sama meskipun usianya sama. Semua itu masuk dalam rumpun keilmuan psikologi yang membahas dan mempelajari bagaimana perilaku dan mentalitas pada diri manusia (Masganti, 2017).

Manusia merupakan makhluk yang senantiasa tumbuh dan berkembang. Pertumbuhan dalam diri manusia terjadi baik pada sisi fisik maupun mentalnya (Y. Safitri, 2017). Perkembangan adalah berubahannya sikap yang terjadi secara berkelanjutan yang melekat dari faktor bawaan \& lingkungan serta menjadi semakin baik pada pribadi seseorang baik secara kuantitatif atau kualitatif (Siti Masruroh, 2018). Setiap fase pertumbuhan dan perkembangan tersebut selalu terjadi perubahan yang dinamis seiring laju usianya. Namun ada satu fase dalam dinamika pertumbuhan dan perkembangan manusia yang menjadi perhatian banyak orang, fase tersebut merupakan fase usia anak-anak. Para ahli menganggap bahwa usia anak-anak merupakan masa emas bagi setiap orang, sebab pada masa ini seorang manusia akan sangat mudah untuk dibentuk perilaku dan pengetahuannya (Priyanto, 2014). Fase ini akan menentukan pada proses perkembangan di masa berikutnya (Sufa \& Setiawan, 2017)

Perilaku dan pengetahuan pada diri anak merupakan hal yang berjalan beriringan dan saling berkontribusi pada diri manusia. Pengetahuan akan mempengaruhi perilaku, sebaliknya perilaku akan mempengaruhi tendensi pengetahuannya. Keduanya menjadi agenda penting dalam proses mendidik seorang anak yang masih belia agar di masa depan ia menjadi orang yang diharapkan oleh masyarakat. Melalui proses pendidikan yang baik, kebaikan pengetahuan dan perilaku akan menjadi garansi sebagai hasilnya. Hal yang banyak dikatakan oleh orang sebagai hal yang masih kurang adalah terkait perilaku para punggawa bangsa yang minus moralitas. Jika ditinjau dari perspektif para ilmuan mereka sependapat bahwa perkembangan moral merupakan salah satu hal yang berperan penting selama proses perkembangan yang dialami oleh anak usia dini (Satomi Izumi, 2013). Oleh karena itu, memahami perkembangan moralitas pada anak adalah hal yang penting untuk dilakukan. Alasan moral menjadi point penting yang harus ditanamkan sedini mungkin dikarenakan moral nantinya akan menjadi penentu bagaimana anak dalam bertingkah laku untuk masa depannya (Putri, 2017).

Tertanamnya nilai moral yang mapan pada anak-anak akan membuatnya mampu berperilaku sopan dan santun kepada siapa pun, mampu menghormati orang lain yang lebih tua darinya, patuh kepada aturan, bersikap sabar, jujur serta mau menghargai orang lain (Nurhayati 
dkk., 2019). Menanamkan nilai moral berarti melatih atau mendidik perkembangan kecerdasan moralnya. Menurut Ananda proses mengembangkan moralitas anak dalam konteks mendidik memiliki beberapa prisnsip yang harus dipahami pendidik atau orang dewasa. Prinsip tersebut antara lain adalah seperti yang diuraikan dibawah ini (Ananda, 2017): a) pendidik harus mampu membina komunikasi yang bagus dengan anak didikannya, agar kelak mereka tidak merasa takut terhadap para pendidik; b) pendidik merupakan contoh bagi anak, sehingga pendidik harus memperlihatkan perilaku yang baik-baik terhadap anak; c) pendidik harus memberikan kelonggaran bagi anak dalam memilih dan berkehendak selama tidak menimbulkan konsekuensi yang besar; d) mengajar dengan bahasa yang sopan; e) emberikan motivasi dan nasehat yang baik bagi anak, bukan memaksa; f) jika seorang anak bersikap tidak baik maka pendidik berusaha untuk meluruskan dan mengendalikan perilaku anak jika berlebihan; g) seorang pendidik tidak boleh asal menghukum, namun ia harus memberikan bimbingan agar anak tidak mengulangi perbuatannya.

Moral atau moralitas merupakan bentuk atau hasil dari nilai-nilai yang hitam putih, yakni antara benar dan salah, sehingga berimplikasi pada aturan yang berpengaruh pada perilaku anak (Fatmawati \& Supriyanto, 2018). Perilaku anak yang baik seperti jujur, disiplin, hormat, taat dan lainnya merupakan sikap yang dituntut ada pada diri anak, karena akan terus berkembang sampai anak dewasa dan memiliki keturunan (Nauli dkk., 2019). Perkembangan moral berkaitan erat dengan tingkat pengendalian diri yang dapat dilakukan seseorang terkait dengan aturan sosial (Ozbey, 2014). Anak-anak membangun moralitas melalui interaksi timbal balik dengan lingkungannya (Dahl \& Killen, 2018).

Hal ini membuktikan perubahan perilaku anak terjadi seiring dengan pertambahan usianya. Lingkungan sekitar juga menjadi acuan perubahan moral anak, sehingga perlunya suatu bimbingan bagi orang tua atau pendidik dalam mengarahkan serta memberikan pembimbingan kepada anak-anak tersebut agar memiliki perkembangan moral yang baik. Perkembangan moral anak rentan terjadi, dikarenakan anak sangat cepat dalam meniru sesuatu meskipun tidak diajarkan secara langsung. Selain itu perkembangan moral anak yang semakin pesat juga menjadi dampak dari perubahan moral anak yang baik atau tidak kedepannya.

Penurunan moral ini terjadi pada setiap individu dengan usia berapapun. Meningkatkan pendidikan moral sejak dini masa kanak-kanak dapat menghentikan kemerosotan moral. Seperti yang dikatakan oleh Arnold Toynbe yang dikutip dari Nilawati Tadjuddin (2018) yang menjadi kontribusi utama penyebab kehancuran suatu kelompok (suatu bangsa) disebabkan oleh melemahnya karakter bangsa itu sendri dalam hal ini berkaitan dengan perkembangan moral seorang individu yang dimulai sejak masih usia dini (Nilawati, 2018). Hal ini dikarena awal 
masa kecil merupakan masa berkembang bagi anak. Dalam masa ini, anak-anak memiliki karakteristik dalam bertingkah (Sesmiarni, 2019). Metode yang seringkali diterapkan pendidik di institusi pendidikan dan para orang tua di keluarga (rumah) dalam membina perilaku anak-anak dibawah asuhannya, yaitu dengan mengjarakan mereka untuk melakukan sesuatu yang mudah dikerjakan anak dan tidak membahayakan, seperti menyapu. Mengajarkan kebiasaan yang baik bagi anak sangat perlu baginya dalam mengahdapi persoalan di sekelilingnya dan di masa mendatang. Seorang anak akan lebih berani dan percaya diri di setiap keadaan dan rintangan (Kusnilawati dkk., 2018).

Menurut Paschalio Loukatari, dkk (2019) dalam penelitiannya mengatakan bahwa banyak penelitian menunjukkan bahwa anak-anak, selama masa transisi dari awal usia kanak-kanak (prasekolah dan sekolah dasar) hingga pendidikan menengah, bebas nilai waktu untuk bermain, berbeda dengan karakter dominan pengawasan orang dewasa selama hari sekolah. Dengan sebab itu, masa sekolah anak adalah masa sekolah yang melakukan kegiatan belajar sambil bermain (Loukatari dkk., 2019).

Berdasarkan hasil kajian beberapa literatur tersebut menunjukkan bahwa perilaku anak dapat berkembang karena mendapat pengaruh dari berbagai bidang. Perkembangan moral anak banyak mengalami perubahan disebabkan oleh lingkungan dan cara orang tua atau pendidik dalam mendidiknya. Perkembangan moral pada anak harus dibimbing dengan baik, karena moral anak akan berpengaruh pada masa depannya. Menurut Irma, dkk dalam penelitiannya mengatakan bahwa orang tua memiliki latar belakang serta sikap yang berbeda, sehingga dalam mendidik anak-anaknya pun akan menghasilkan perilaku yang berbeda pada anak yang satu dengan anak yang lainnya (Irma dkk., 2019). Oleh karena itu, maka kemudian peneliti tertarik untuk mengkaji ulang tentang penyebab yang bisa memberikan pengaruh bagi perkembangan moral anak, khususnya yang berusia dini

\section{METODE PENELITIAN}

Penelitian yang dilaksanakan ini merupakan penelitian dengan pendekatan penelitian kualitatif, serta menggunakan metode studi pustaka atau library research. Analisisnya merupakan analisis deskriptif, sehingga menghasilkan data yang deskriptif. Sebagaimana dikatakan oleh Bogdan dan Taylor, bahwasanya hasil dari sebuah penelitian dengan desain kualitatif adalah data atau informasi yang bersifat deskriptif (Moleong, 2014). Sehingga penelitian kualitatif deskriptif merupakan sebuah penelitian yang dilakukan terhadap sebuah kejadian dengan mengumpulkan beberapa data atau informasi kemudian menganalisisnya dan menjadikannya sebuah data baru yang sesuai dengan tema. 
Penelitian ini tidak seperti eksperimen, akan tetapi hanya mengkaji terkait gejala, variabel atau situasi (Fenti Hikmawati, 2017). Sebagaimana menurut Yin, penelitian ini mengarah pada kontribusi pengetahuan yang telah ada yang mungkin dapat membantu menjelaskan perilaku sosial manusia (Yin, 2011). Adapun metode yang diambil pada penelitian ini adalah penelitian pustaka dengan menganalisis beberapa teori dari kepustakaan yang membahas tentang faktor yang memberi dampak terhadap tingkat pertumbuhan dan pengembangan moral atau moralitas anak-anak yang berusia dini (Mirzaqon \& Purwoko, 2018).

Adapun sumber referensi yang diambil bersumber dari data-data yang dikumpulkan dari hasil penelitian kepustakaan dengan menganalisis teori-teori yang didasarkan atas buku-buku, jurnal, dan lainnya dengan tema faktor yang berpengaruh terhadap perkembangan moral anak berusia dini. Jadi, sumber data yang peneliti pergunakan dalam penelitian ini adalah berupa hasil dari analisis penelitian literature yang peneliti ambil dari jurnal ilmiah yang dapat diakses melalui web ditambah dengan refrensi buku yang telah lebih dahulu ada.

Metode dalam mengumpulkan data juga didasarkan atas dokumentasi. Pendokumentasian data adalah kumpulan dari data-data atau dokumen yang sebelumnya telah dianalisis (Husaini Usman, 2014). Cenderung data yang bersifat dokumen dijadikan sebagai sumber sekunder dalam penelitian. Jadi dapat dinyatakan bahwa dokumentasi merupakan suatu kelengkapan yang disediakan berupa dokumen- dokumen tertentu yang diperlukan dalam proses penelitian. Metode yang diambil ini didasarkan juga atas teori dari Miles dan Huberman. Teknik analisis data dilakukan bertujuan untuk mengetahui fenomena terkait faktor-faktor yang mempengaruhi pengembangan moral anak yang berusia dini. Jadi, penelitian ini akan dilakukan melalui proses studi kepustakaan atau metode kepustakaan, sehingga data-data akan diperoleh dari hasil analisis buku-buku dan jurnal-jurnal ilmiah.

Menurut Miles dan Huberman, analisis data dapat dilakukan dengan tiga cara, yaitu (Sugiyono, 2014), yaitu reduksi data, penyajian data dan gambaran atau kesimpulan. Reduksi terhadap kumpulan data adalah tahap memilih dan merangkum hal-hal yang penting dari data yang dikaji. Penyajian data adalah tahap disajikannya data dengan singkat, jelas dan padat. Penarikan kesimpulan, yaitu memberikan kesimpulan dan verifikasi dari penelitian yang dilakukan. Ketiga proses tersebut berjalan secara hirarkis, sehingga analisis yang dihasilkan dalam kajian ini tertata dan mendalam.

Berdasarkan hal yang telah dijelaskan sebagaimana sebelumnya, maka peneliti menentukan langkah-langkah penelitian. Langkah-langkah tersebut tentu sesuai dengan konsep penelitian studi pustaka. Sehingga, langkah-langkah penelitian kepustakaan ini adalah sebagai berikut: 
1) Mengumpulkan mengenai data-data yang relevan melalui buku-buku, dokumen, jurnal maupun majalah internet.

2) Menganalisa atau mengamati data-data yang akan diteliti, sehingga peneliti dapat menyimpulkan masalah yang akan dikaji secara lebih terperinci.

\section{HASIL PENELITIAN DAN PEMBAHASAN}

a. Perkembangan Moral Anak Usia Dini

Arti dari kata moral yang sesungguhnya adalah yang sesuai dengan bahasa latin, yakni perilaku, adat atau kebiasaan. Pada kehidupan sosial, moral merupakan kesesuaian dan ketaatan terhadap aturan-aturan yang dibangun di sebuah masyarakat dan harus ditaati oleh setiap anggotanya. Dalam mengembangkan moral anak, saat anak masih berusia dini mereka diajarkan tentang benar dan salah. Pada usia selanjutnya anak diberikan pemahaman terkait mengapa sebuah perilaku dapat dikatakan baik dan salah. Faktor yang paling memberikan dampak bagi pertumbuhan perilaku anak adalah lingkungan sekitar mereka. Sehingga orang tua dan keluarga anak harus benar-benar dikontrol dan diawasi perkembangan dan pergaulannya (Rakimahwati, 2012). Moral menurut Wila Huky dalam Latifah Nurul Safitri, mengatakan bahwa pengertian komprehensif dari moralitas adalah sebagai berikut (L. N. Safitri \& Aziz, 2019): 1) perilaku yang dibangun berdasarkan ide-ide yang disepakati oleh suatu kelompok; 2) pendidikan yang berkaitan dengan sikap dan tingkah laku seseorang; 3) nilai-nilai yang harus dituruti oleh setiap individu.

Moral bukanlah bawaan lahir dari seorang manusia, manusia yang baru lahir tidak mengenal masalah moral. Moralitas merupakan sesuatu yang diajarkan atau ditanamkan pada seorang manusia setahap demi setahap mulai dari dirinya menghidup udara dunia. Dengan demikian, ia akan mampu memahami serta mengaplikasikan moral yang tertanam dalam dirinya tersebut. Oleh karena itu, moral atau moralitas merupakan sisi dalam diri manusia yang berkembang seiring dengan perkembangan dirinya (Raihana \& Wulandari, 2017). Artinya, moral atau moralitas berkembang sejalan dengan berkembangnya kemampuan kognitif seseorang. Jadi secara logika matematis dapat disimpulkan bahwa semakin bertambahnya umur manusia maka kemampuan kognitifnya semakin berkembang, sehingga ia dapat berperilaku dengan moralitas yang baik. Namun, pada tataran realitas, tidak semuanya berkembang sejalan sebagaimana yang diidealkan.

Usia dini merupakan usia tatkala anak sangat memerlukan kontol yang penuh atas aktifitas serta pertumbuhan dan perkembangannya. Pada masa ini, peran orang tua sanga intensif diperlukan. Perkembangan dalam diri anak bukan sekedar pertumbuhan dan perkembangan fisik, 
namun juga pada perkembangan psikisnya, yang termasuk di dalamnya perkembangan moralitas. Proses perkembangan moral pada diri anak akan berpengaruh terhadap perilaku atau sikap yang diaktualisasikan olehnya kepada orang tua maupun terhadap sesamanya (Kasmadi, 2019).

Perkembangan perilaku pada setiap anak tidaklah sama, ada yang perkembangan moralnya dinilai sangat patut dan ada pula yang memiliki perkembangan moral yang sangat kurang. Perkembangan moral merupakan salah satu proses perubahan yang terjadi sepanjang hidup manusia baik itu tingkah laku, budi pekerti, akhlak maupun pembentukan karakter pada anak seiring bertambahnya usia anak. Perkembangan tersebut terjadi pada sebagian besar mental anak, namun ada juga pada fisik dari anak (Nurjanah, 2018). Perkembangan moral anak harus menjadi perhatian setiap orang tua. Hal ini bertujuan untuk mengajarkan seorang anak agar dapat membedakan yang benar maupun salah, sehingga anak dapat berperilaku dengan baik (Usakli, 2010). Moralitas anak tidak merupakan warisan orang tua, melainkan didapat dengan penanaman nilai-nilai pada anak (Ashfi, 2016). Akan Tetapi orang tua mempunyai tugas \& dan tanggung jawab dalam menanamkan nilai-nilai moral kepada putra-purtrinya. Seperti dalam hal misalnya ketika anak melakukan kesalahan, maka tugas orang tua adalah menegurnya dengan baik dan memberikan penjelasahan kenapa ia ditegur, dan juga menjelaskan kepadanya bahwa sesuatu yang ia lakukan itu adalah perbuatan yang salah, serta berikan contoh yang benar utuk memperbaiki kesalahan yang ia lakukan. Pengasuhan yang demikian ternyata memainkan pengaruh yang luar biasa terhadap efektivas dalam pembentukan moral yang terjadi dalam diri anak. Moral adalah norma dan aturan sosial yang dirancang untuk memandu perilaku individu dalam suatu masyarakat (Benlahcene \& Zainuddin, 2018).

Berdasarkan penjelasan sebelumnya, dapat diambil kesimpulan bahwa pengaruh pengembangan moralitas anak merupakan salah satu perubahan tingkah laku, perilaku maupun akhlak pada anak seiring dengan bertambahnya usia. Oleh karena itu, perkembangan moral pada anak sangat mempengaruhi masa depan anak. Hal ini membuktikan bahwa perkembangan moral pada anak tidak ada dalam dirinya sewaktu dilahirkan, namun tumbuh dan berkembang selaras dengan kondisi lingkungan dan bimbingan dari orang tua maupun pendidiknya.

b. Tahapan Perkembangan Moralitas Anak Usia Dini

Perkembangan moralitas pada anak, diakibatkan karena adanya bantuan dari beberapa hal berikut, yaitu pembentukan kepribadian, pembentukan karakter, dan perkembangan sosial. Perkembangan pada diri anak tersebut banyak dipengaruhi oleh aktivitas sosial dari orang-orang terdekat dari anak, seperti keluarga dan lingkungan tempat tinggal anak (Inawati, 2017). Oleh sebab itu, orang tua atau lebih umumnya keluarga harus terus memberikan sajian pendidikan 
yang baik bagi anak dan juga tetap mengontrol dan menjaga anaknya dari pengaruh didekatnya dan lingkungan sosial.

Adapun tahapan perkembangan moral anak, seperti yang dijelaskan oleh Piaget adalah fase-fase perkembangan perilaku anak, yang terbagi menjadi dua, yaitu: moralitas kerja sama dan moralitas otonomi. Pada fase yang pertama anak berusaha untuk beradaptasi dengan lingkungan dan mencoba untuk berkerjasama dengan dengan orang-orang di sekitarnya. Sedangkan pada fase yang kedua anak akan mencoba untuk beradaptasi dengan nilai-nilai dan aturan yang ada di sekitar mereka. Kohlberg menyebutkan bahwa terdapat tiga tahap. Tahap yang pertama merupakan tahapan yang dilalui anak dalam mentaati nilai-nilai dan aturan-aturan serta hukuman-hukuman di sekelilingnya. Tahap yang kedua merupakan tahapan yang bagi anak untuk memperoleh penghargaan sosial. Sedangkan tahap yang ketiga yaitu tahapan bagi anak dalam menjalin hubungan dengan setiap orang dan mencoba untuk beradaptasi dengan lingkungan sosial yang lebih luas (Hasanah, 2019).

c. Faktor yang Berpengaruh Pada Perkembangan Moral Anak Usia Dini

Perkembangan moral yang terjadi pada diri anak yang berusia dini disebabkan oleh beberapa faktor, yakni faktor yang ada dalam diri anak secara alami maupun faktor yang ada dari luar diri pribadinya. Kedua faktor tersebut dapat dikatakan sebagai faktor individu manusia itu sendiri dan faktor sosial di sekelilingnya (Pranoto, 2017). Kedua faktor tersebut berkontribusi besar dalam membentuk atau mengasah moralitas seorang anak.

Perkembangan tersebut dapat berupa keadaan situasi lingkungan, konteks individu, atau kepribadian seseorang dalam konteks sosial atau cara berintraksi dengan lingkungan sekitar dalam bermasyarakat. Hal ini membuktikan bahwa perlu adanya eksistensi dari orang tua atau pendidik untuk membimbing anak berusia dini, karena hal eksistensi atau peran tersebut akan memberikan pengaruh signifikan terhadap perkembangan yang terjadi pada diri anak dalam rentang masa yang mendatang. Secara umum, faktor tersebut dapat peneliti gambarkan sebagaimana dalam gambar berikut ini:

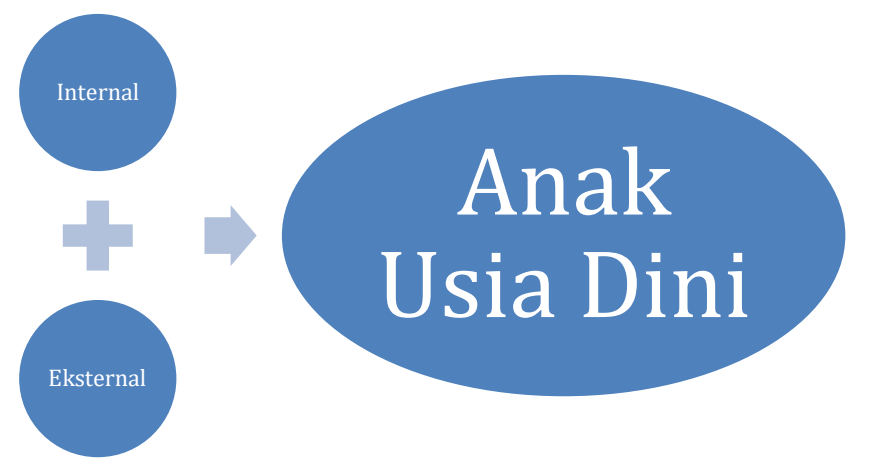


Gambar 1.Faktor Yang Mempengaruhi Perkembangan Moral AUD

Berdasarkan ilustrasi gambar di atas, maka dapat kita tarik simpulan bahwasanya terdapat dua buah faktror yang mendominasi terhadap proses perkembangan anak usia dini. Faktor dalam diri anak merupakan faktor utama yang akan mempengaruhi arah perkembangan moralitasnya, sementara faktor eksternal merupakan faktor dari luar yang akan ikut berpengaruh pada perkembangan moralitasnya. Kedua faktor tersebut saling bertaut antara faktor yang satu dengan faktor yang lainnya, sebab seorang anak terlahir sebagai pribadi mandiri yang akan bersosialisasi dengan lingkungannya. Kedua faktor tersebut harus bisa dikontrol dengan baik agar perkembangan moral yang terdapat pada anak berusia dini dapat berkembang secara optimal seperti yang diharapkan oleh semua pihak.

Menurut Berns, dalam Pranoto, mengatakan terdapat tiga keadaan yang bisa memberikan pengaruh terhadap moralitas anak, yaitu situasi, individu dan sosial (Pranoto \& Khamidun, 2019). Adapun ketiganya peneliti lihat dari kacamata yang sedikit berbeda sebagaimana berikut:

1) Keadaan atau situasi yang ada di dekat anak atau hubungan dengan lingkungan sosial.

Keadaan atau situasi merupakan hal di mana seorang anak berada dalam konteks kehidupannya. Konteks kehidupan yang dimaksud adalah keadaan sosial yang di dalamnya terdapat norma-norma kemasyarakatan. Artinya tempat seorang anak berada dan bersosialisasi memiliki segugus norma yang akan ia lihat, ia alami bahkan dinegosiasi olehnya. Keadaan yang dilalui oleh seseorang akan menempa dirinya, memberikan pengertian dan pengetahuan baginya tentang moralitas. Misalnya, keadaan sosial seorang anak yang dilahirkan dari keluarga keraton yang memungkinkan berbeda dengan anak yang terlahir dari lingkungan masyarakat umum. Keadaannya yang terlahir demikian akan membawa pada moralitasnya yang bertendensi mengikuti moralitas kalangan keraton, sebab dalam kalangan keraton terdapat norma-norma benar salah yang mengikat dan sedikit berbeda dengan konteks pada masyarakat umumnya. Begitu pula konteks kedaerahan yang memiliki perbedaan antara daerah yang satu dengan daerah-daerah yang lainnya. Jadi, dapat dikatakan bahwa keadaan yang ada pada sekeliling anak merupakan hal yang akan berbuntut pada perilaku moral yang diaktualisasikan olehnya.

2) Konteks individu yang memiliki fitrah.

Konteks individu merupakan konteks diri pribadi seorang anak. Seorang anak lahir dengan fitrah atau potensi yang akan membuatnya memiliki karakteristik tertentu. Fitrah ini bukanlah moral, namun bawaan yang diberikan oleh Tuhan. Oleh karena itu, Seorang anak 
tentunya memiliki berbagai karakter yang berkait dengan dirinya, baik itu potensi akal maupun hati. Kedua potensi ini akan dapat berkembang melalui proses pendidikan yang dilaluinya serta proses interaksi sosial yang menimbulkan pemahaman akan nilai atau norma. Sebagaimana telah dijelaskan sebelumnya, bahwa moralitas bukanlah bawaan lahir yang bersifat given, moralitas merupakan proses panjang dari seorang manusia untuk mengetahui dan bertingkah laku sejalan dengan berbagai norma ataupun nilai yang dianut olehnya dan oleh konteks sekelilingnya. Sehingga, perlu dilakukan penggemblengan moral agar seorang anak dapat berlaku dengan moral yang baik. Contoh kecil dari hal ini adalah pada anak yang sejak kecil tinggal di hutan sampai ia dewasa dan dirawat oleh mamalia lain selain manusia, maka ia tidak mendapatkan proses penggemblengan moral, oleh sebab itu tatkala ia menemukan dunia sosial pada manusia, moralitasnya tidak sama sebagaimana manusia pada umumnya.

Proses penggemblengan moral pada anak merupakan proses yang harus dikontrol dan diarahkan oleh orang tua atau pendidiknya. Melalui hal ini, seorang anak akan mampu melakukan analogi terhadap berbagai konstruksi pengetahuan yang ia miliki terhadap cara ia berlaku di dalam kehidupannya, sehingga ia akan mampu berlaku dengan moral yang baik. Prosesnya berjalan secara natural dalam akal dan nuraninya. Sehingga konteks individu ini menjadi penentu yang sangat besar terhadap perkembangan moralitas pada diri anak.

3) Konteks sosial, yaitu terdiri dari: keluarga, teman seumur (teman sebaya), media masa, institusi pendidikan dan masyarakat.

Konteks sosial merupakan hal yang pasti dilalui oleh setiap orang, termasuk bagi anak yang berusia dini. Konteks sosial memainkan peran memberikan pengalaman dan pengetahuan yang akan diserap dalam diri para anak. Artinya, melalui konteks sosial anak berusia dini akan belajar, jika dikaitkan dengan lingkungan pendidikan, maka institusi keluarga menjadi yang pokok, dilanutkan dengan institusi masyarakat yang mana para anak berusia dini menghabiskan waktu mereka untuk berinteraksi dan bersosialisasi melalui bermain, serta institusi pendidikan yang juga menjadi wadah bagi para anak berusia dini untuk digembleng secara intelektual maupun kejiwaannya. Peran institusi-institusi ini sangat penting yang akan mendukung proses penanaman dan pembentukan moralitas pada anak berusia dini.

Ketiga hal yang telah peneliti jelaskan di atas merupakan faktor-faktor yang memberikan sumbangsi pengaruh terhadap perkembangan moral pada anak berusia dini. Hal tersebut perlu dipentingkan serta diperhatikan oleh para orang tua dan institusinya yakni keluarga, serta oleh para pendidik dalam institusi pendidikan, utamanya dalam proses mendidik anak agar tidak salah dalam bergaul dan beradaptasi dengan lingkungan. Menurut Harlock, yang dikutip oleh 
Maharani (2014) terdapat penyebab yang bisa memberikan pengaruh bagi moralitas anak, yaitu (Maharani, 2014): (1) pengetahuan terhadap perilaku baik dan buruk sehingga membutuhkan pengambilan keputuasan yang harus dilakukan anak (2) adanya rasa salah dalam diri anak dan malu jika harus melakukan tindakan yang salah (3) peranan dari kondisi sosial anak, sehingga anak akan cenderung apa yang ia lihat di lingkungannya sebab anak merupakan peniru yang ulung.

Berdasarkan penjelasan beberapa para ahli sebelumnya, maka bisa diambil kesimpulan, bahwa perkembangan moralitas pada anak usia dini tidak tumbuh sejak lahir, namun terus berkembang seiring didapatkannya berbagai pengalaman dalam rentang usia anak. Perkembangan pada anak berusia dini dipengaruhi oleh dua faktor, yakni faktor internal atau faktor dalam dan faktor eksternal atau luar. Faktor internal atau faktor dalam merupakan faktor kepribadian individu yang telah dikaruniai berbagai potensi, baik akal maupun nurani. Sementara itu, faktor lain yang berpengaruh pada perkembangan moral anak usia dini adalah faktor dari luar dirinya atau faktor eksternal. Faktor eksternal atau faktor luar ini terdiri atas konteks atau keadaaan di mana ditinggali olehnya dan konteks sosial atau cara proses interaksinya dengan lingkungan sosial di sekitarnya. Dengan demikian maka orang tua atau pendidik perlu untuk membimbingnya agar kelak ia memiliki perkembangan moral yang baik serta dapat mengaktualisasikan moralitasnya secara baik.

\section{SIMPULAN DAN SARAN}

Berdasarkan kajian yang peneliti lakukan melalui data-data literatur yang didapatkan, penulis menyimpulkan beberapa hal. Pertama, perkembangan moral pada anak berusia dini merupakan rangkaian proses panjang yang didapatkan oleh anak melalui pengalaman, pengajaran dan pendidikan tentang hal yang salah dan hal yang benar. Proses tersebut terjadi dikarenakan moral atau moralitas pada diri manusia bukanlah sesuatu yang bersifat bawaan. Meski bukan bersifat bawaan, potensi nurani dan akal manusia adalah titik awal untuk tertanamnya moralitas bagi anak yang berusia dini. Kedua, proses perkembangan moral ini dipengaruhi oleh dua faktor, yakni faktor internal atau yang ada dalam diri individu anak dan faktor eksternal yang hadir dari luar individu anak. Hal ini terjadi karena proses perkembangan moral ini berlangsung selama rentang usia anak yang akan berimplikasi pada aktualisasi perilakunya. Faktor internal merupakan faktor dalam diri manusia yang kompleks dengan bekal akal dan nurani dari Tuhan. Sementara faktor eksternal merupakan faktor dari luar diri anak, yakni dari konteks atau keadaan lingkungan sosial tempat ia hidup dan dari proses interaksi atau sosialisasi yang ia lakukan dengan lingkungan sosialnya. Oleh sebab itu, maka perlu adanya suatu proses pembelajaran pada anak 
mengenai nilai-nilai positif yang akan membentuknya menjadi anak yang secara moral dikatakan baik, sehingga perkembangan moral pada anak dapat berkembang secara optimal.

Peneliti berharap agar hasil kajian ini dapat bermanfaat bagi siapa saja yang menelaahnya. Adapun peneliti juga memiliki beberapa saran terkait dengan hasil kajian ini yakni:

1) Untuk para orang tua diharapkan agar memperhatikan pola asuh yang benar dan mendidik anak dengan sebaik mungkin agar tidak terjadi kemerostan moral pada anak, serta memberikan stimulasi yang baik agar perkembangan anak bisa berkembang secara optimal.

2) Untuk para pendidik hendaknya memiliki pemahaman yang cukup mengenai pendidikan anak yang berusia dini, terlebih lagi dalam hal penanaman moral pada anak dan harus menggunakan strategi yang tepat dan juga menyenangkan yang disukai oleh anak-anak, sehigga mereka merasa senang dan bahagia pada saat mengikuti proses pembelajaran yang sedang berlangsung, dengan begitu tujuan pendidikan yang telah digariskan dapat dicapai dengan perolehan hasil yang baik.

3) Untuk para peneliti selanjutnya, peneliti mengharapkan untuk melakukan kajian lebih lanjut dalam lapangan mengenai pemahaman orang tua di terhadap perkembangan moral anak berusia dini secara lebih kreatif lagi.

\section{DAFTAR PUSTAKA}

Abderramane Benlahcene, Ruslan Bin Zainuddin, N. S. A. Bt. I. (2018). A Study on Moral Reasoning among Managers of the State-owned Companies in Algeria. Internasional Journal of Academic research in Economics \& Management Sciences, 7(3), 89-100. https://doi.org/10.6007/IJAREMS/v7-i3/4438

Ananda, R. (2017). Jurnal Obsesi: Jurnal Pendidikan Anak Usia Dini Implementasi Nilai-nilai Moral dan Agama pada Anak Usia Dini. Pendidikan Anak Usia Dini, 1(1), 19-31. https://doi.org/10.31004/obsesi.v1i1.28

Aris Priyanto. (2014). Pengembangan Kreativitas Pada Anak Usia Dini Melalui Aktivitas Bermain. Jurnal Ilmiah Guru Caraka Olah Pikir Edukatif, O(2).

Dahl, A., \& Killen, M. (2018). A developmental perspective on the origins of morality in infancy and early childhood. Frontiers in Psychology, 9(SEP), 1-6. https://doi.org/10.3389/fpsyg.2018.01736

Fatmawati, N., \& Supriyanto, D. (2018). Pengaruh Metode Bercerita (Tentang Kisah - Kisah Nabi dan Rosul) Terhadap Perkembangan Nilai Agama dan Moral Anak Usia 4-5 Th di 
RA. Perwanida Raci Kecamatan Bangil Kabupaten Pasuruan Tahun Ajaran 2017-2018. PROCEEDING: The Annual International Conference on Islamic Education, 3(2), 332337. http://jurnal.stitnualhikmah.ac.id/index.php/proceedings/article/view/285

Fenti Hikmawati. (2017). Metodelogi Penelitian. Rajawali Pers.

Hasanah, E. (2019). Perkembangan Moral Siswa Sekolah Dasar Berdasarkan Teori Kohlberg. Journal UNY, 6(2), 131-145.

Husaini Usman, S. A. (2014). Pengantar Statistika. Bumi Aksara.

Inawati, A. (2017). Strategi Pengembangan Moral dan Nilai Agama Untuk Anak Usia Dini. Jurnal Pendidikan Anak, 3(1), 51-64.

Irma, C. N., Nisa, K., \& Sururiyah, S. K. (2019). Keterlibatan Orang Tua dalam Pendidikan Anak Usia Dini di TK Masyithoh 1 Purworejo. Jurnal Obsesi : Jurnal Pendidikan Anak Usia Dini, 3(1), 214. https://doi.org/10.31004/obsesi.v3i1.152

Kasmadi, N. (2019). Pola Asuh Orang Tua Dalam Pembinaan Moral Anak Usia Dini. SMART KIDS: Jurnal Pendidikan Islam Anak Usia Dini, 1(2), 17-24. http://smartkids.ftk.uinjambi.ac.id/index.php/smartkids/article/view/35

Kusnilawati, K., Fauziddin, M., \& Astuti, A. (2018). Meningkatkan Aspek Perkembangan Nilai Agama dan Moral Anak Usia Dini dengan Penerapan Metode Bercerita Tema Islami. Aulad: Journal on Early Childhood, 1(1), 28-38. https://doi.org/10.31004/aulad.v1i1.4

Laila Maharani. (2014). Perkembangan Moral Pada Anak Laila Maharani. Jurnal Bimbingan dan Konseling, 01(2), 93-98.

Loukatari, P., Matsouka, O., Papadimitriou, K., Nani, S., \& Grammatikopoulos, V. (2019). The Effect of a Structured Playfulness Pogram on Sosial Skills in Kindergarten Children. Internasional Journal of Instruction, 12(3), 237-252. https://doi.org/doi.org/10.29333/iji.2019.12315a

Masganti. (2017). Psikologi Perkembangan Anak Usia Dini. Kencana.

Mirzaqon, A., \& Purwoko, B. (2018). Studi Kepustakaan Mengenai Landasan Teori Dan Praktik Konseling Expressive Writing Library. Jurnal BK UNESA, 1, 1-8.

Moleong, L. J. (2014). Metodologi Penelitian Kualitatif. PT Remaja Rosdakarya.

Nauli, V. A., Karnadi, K., \& Meilani, S. M. (2019). Peran Ibu Pedagang Pasar 24 Jam Terhadap Perkembangan Moral Anak (Penelitian Studi Kasus di Kota Bekasi). Jurnal Obsesi : Jurnal Pendidikan Anak Usia Dini, 3(1), 241. https://doi.org/10.31004/obsesi.v3i1.179

Nurhayati, N., Awalunisah, S., \& Amrullah, A. (2019). Keefektifan Metode Role Play Terhadap Nilai Moral Anak Usia 5-6 Tahun. Jurnal Akrab Juara, 4(2), 181-195. http://akrabjuara.com/index.php/akrabjuara/article/view/576 
Nurjanah, S. (2018). Perkembangan Nilai Agama Dan Moral (Sttpa Tercapai). Jurnal Paramurobi, 1(1).

Nilawati Tadjuddin. (2018). Early Children Moral Education In View Psychology, Pedagogic And Religion. Al-Atfhal Jurnal Ilmiah Pendidikan Anak Usia Dini 1(1). https://doi.org/10.24042/ajipaud.v1i1.3386

Ozbey, S. (2014). A Study on Preschool Children's Perceptions of Moral and Social Rules. International Journal of Humanities and Social Science, 4(11), 149-159.

Permata Ashfi, W. W. (2016). Status Ibu Dan Pengaruhnya Dalam Kecerdasan Moral Anak PraSekolah. jurnal indigenous, 1(2), 62-70.

Pranoto, Y. K. S. (2017). Kecerdasan Moral Anak Usia Prasekolah. Edukasi, 2(1), Article 1. https://journal.unnes.ac.id/nju/index.php/edukasi/article/view/962

Pranoto, Y. K. S., \& Khamidun, K. (2019). Kecerdasan Moral: Studi Perbandingan pada Anak Usia 4-6 Tahun. Prosiding Seminar Nasional Pascasarjana (PROSNAMPAS), 2(1), 498511.

Putri Hana Pebriana. (2017). Ananlisis Kemampuan Berbahasa dan Penanaman Moral Pada Anak Usia Dini Melalui Metode Mendongeng, 1 https://doi.org/10.31004/obsesi.v1i2.25

Raihana, P. A., \& Wulandari, W. (2017). Status Ibu dan Pengaruhnya dalam Kecerdasan Moral Anak Pra-Sekolah. Indigenous: Jurnal Ilmiah Psikologi, 1(2), Article 2. https://doi.org/10.23917/indigenous.v1i1.2905

Rakimahwati, Y. (2012). Upaya Meningkatkan Perkembangan Moral Anak Usia Dini Melalui Mendongeng Di Tk Dharmawanita Improving the Moral Development of Early Age Children. jurnal Ilmiah Visi P2TK PAUD NI, 7(1), 18-41.

Safitri, L. N., \& Aziz, H. (2019). Pengembangan nilai agama dan moral melalui metode bercerita pada anak. Jurnal Ilmiah Tumbuh kembang Anak Usia Dini, 4(1), 85-96.

SATOMI IZUMI-TAYLOR \& JERRIE C. SCOTT. (2013). Nurturing Young Children's Moral Development through Literature in Japan and the USA. Research in Comparative and International Education, 8(1). http://dx.doi.org/10.2304/rcie.2013.8.1.38

Safitri, Y. (2017). Faktor-Faktor yang Berhubungan dengan Perkembangan Bahasa Balita di UPTD Kesehatan Baserah Tahun 2016. Jurnal Obsesi: Jurnal Pendidikan Anak Usia Dini, 1(2), 148-155-155. https://doi.org/10.31004/obsesi.v1i2.35

Sesmiarni, Z. (2019). The Effective Moral Education on Early Childhood As an Effort Against Immoral Culture. Jurnal Obsesi: Jurnal Pendidikan Anak Usia Dini, 3(2), 561. https://doi.org/10.31004/obsesi.v3i2.191 
Siti Masruroh. (2018). Implementasi Nilai Agama dan Moral pada Anak Usia Dini melalui Urutan Wudhu. Golden Age: Jurnal Pendidikan Anak Usia Dini, 2(1). https://doi.org/10.29313/ga.v2i1.3854

Sufa, F. F., \& Setiawan, H. Y. (2017). Analisis Kebutuhan Anak Usia Dini Usia 4-6 Tahun Pada Pembelajaran Berbasis Komputer Anak Usia Dini. RESEARCH FAIR UNISRI, 1(1).

Sugiyono. (2014). Metode Penelitian Kuantitati fKualitatif dan RND. Alfabeta.

Usakli, H. (2010). Early childhood education: The case of Turkey. Sage Journals, 11(2), 215218. https://doi.org/10.2304/ciec.2010.11.2.215

Yin, R. K. (2011). Qualitative Research from Start to Finish (9 ed.). The Guilford Press. 